\author{
BMC JOURNAL OF SCIENTIFIC RESEARCH \\ A Multidisciplinary Research Journal \\ ISSN: 2594-3421
}

\title{
Diversity of Urban Mammals in Bharatpur Metropolitan City, Chitwan, Nepal
}

\section{Budhan Chaudhary*}

\begin{abstract}
The study of diversity of mammals was accomplished in the urban areas of Bharatpur Metropolitan City, a prime location of Nepal and confined in $433 \mathrm{~km} 2$; consists tropical climate and harbor variety of wildlife since the location is connected with Narayani River, community forests and Chitwan National Park. During data collection by direct observation, hearing sound calls and land marks left, the study was conducted from January to July 2016 for six months. Altogether, 12 families with 28 species of mammals were recorded in which 53.75\% (15/28) were Temporary Living (TL) and 46.42\% (13/28) were Permanent Living (PL). Out of 12 families; Soricidae had the highest, $21.43 \%$ (6/28) of species; followed by Cercopithecidae, Cervidae and Vespertilionidae, 10.71\% (3/28); Canidae, Felidae, Herpestidae, Muridae, and Viverridae, 7.14\% (2/28); and Mustelidae, Rhinocerotidae, and Suidae with 3.57\% (1/28) each. Total Five different IUCN categories; Endangered (EN), Vulnerable (VU), Near Threatened (NT), Data Deficient (DD) and Least Concerned (LC) were closely observed. Among them, LC had the highest, 64.29\% (18/28) of species followed by VU, 21.43\% (6/28); EN, 7.14\% (2/28); and CR, DD equally with 3.57\% (1/28). Paradoxurus hermaphroditus pallasi, is an Asian Palm Civet, which is reported for the first time from Bharatpur, Chitwan, Nepal. The possible factors responsible to attract wildlife in urban areas were availability of seasonal cultivated crops, fruiting and flowering plants; and household organic wastes. But; the increasing traffics stray dogs, and lack of hidings led to threat to wild mammals. The cutting down of trees in the private areas and frequent road killings also amplify risk of small wild mammals.
\end{abstract}

Key words: Civet, ex-situ, traffics. urban, wildlife.

\section{Introduction:}

The diversity of mammals is unique in Nepal where $4.2 \%(n=208)$ of the total world's mammals (WWF, 2012; IUCN, 2018) with 37 families and 192 species are living (Thapa, 2014). Out of 741 threatened species of the world's mammals, 28 species were found in Nepal and two species are endemic (NEMC, 2017). Chitwan National Park is the home for 68 species of mammals (CNP, 2018), which increases chances of wildlife to visit urban areas of Bharatpur Metropolitan City which is a prime location of Nepal and comprises $433 \mathrm{~km}^{2}$ (CD, 2018) with tropical climates. The area is located in the altitude of 181 to $271 \mathrm{~m}$. from the Sea level and bounded by Baranda-bhar corridor in the East; Narayani River and Chitrawan Municipality in the West; Narayani River and Nawalparasi District in the North; whereas Narayani Municipality is in the South (CD, 2018).

\footnotetext{
* Mr. Chaudhary is Lecturer in Zoology at Birendra Multiple Campus (Tribhuvan University)
} 
Altogether, 25\% of the land covers with the protected area (IUCN, 2018) with 118 diverse ecosystems (DNPWC, 2018). In case of animal food providing plants, over 400 species of agrohorticultural crops and 200 species of the vegetables were available (CBD, 1997 and 2014). The variation in climates in agro-ecological zones, favors for the crop and ultimately increase the animal diversity. Nepal's 42\% of population is living in 263 Municipalities (Wikipedia, 2017). The overgrowing human population in urban areas also pressurizes to cut down trees (Dickman, 1987) that loss habitat for wildlife.

Nevertheless, the study is still insufficient to investigate about the situations of the wildlife in ex-situ habitats. The unprotected places are rich with agricultural products which can fulfill their foods, but increasing traffics, stray dogs and lack of hidings can lead to the great threat to mammals. The cutting of trees of the private areas may add problems in living. Therefore, wildlife is in the verge of threat due to human behaviour in their ex-situ habitat although mammals are adjustably shifting to human dwellings. The government policy declares no impunity to wildlife damage although; there has happened much coincidence either with local people or with wild animals to death.

\section{Objectives:}

\subsection{Main Objectives:}

The main purposes of research work were to enlist the species of mammals living in urban area at Bharatpur Metropolitan City and to prepare IUCN, 2018 categories.

\subsection{Specific Objectives:}

- To identify species of mammals.

- To prepare checklists of mammals.

- To report categories of IUCN, 2018 of mammals.

\section{Materials and Methods:}

\subsection{Study Area:}

The study area was selected to Bharatpur Metropolitan City consisting 29 wards and enclosed within $433 \mathrm{~km}^{2}$, which is $19.34 \%$ of the total $\left(2,238.39 \mathrm{~km}^{2}\right)$ area of Chitwan District and located at the altitude of 181 to $271 \mathrm{~m}$. from the Sea-level (BN, 2018). The area is bounded by Narayani River and Nawalparasi District in the North; Narayani Municipality and Chitwan National Park in the South; Barandabhar corridor in the East; and Chitrawan Municipality and Narayani River in the West. The latitudes of this area is $27^{0} 34^{\prime}$ to $27^{\circ} 45^{\prime}$ North, and $84^{\circ} 19^{\prime}$ to $84^{\circ} 29^{\prime}$ South (CD, 2018; and BN, 2018). The record of mammals from thin and private agroforests, human dwellings and crop fields were also performed.

\subsection{Data Collection:}

The primary data collection was completed by direct observation of mammals using binoculars. Out of 29, 10 wards were selected as study blocks (i.e. ward no. 1, 2, 3, 8, 9, 10, 11, 12, 23 and 
26). Each block was visited in 10 different days in evening and in the morning times to record mammals. The direct observation and photographs taking, sound call noticed, and observing markings left in the fields were also used to notice the mammals.

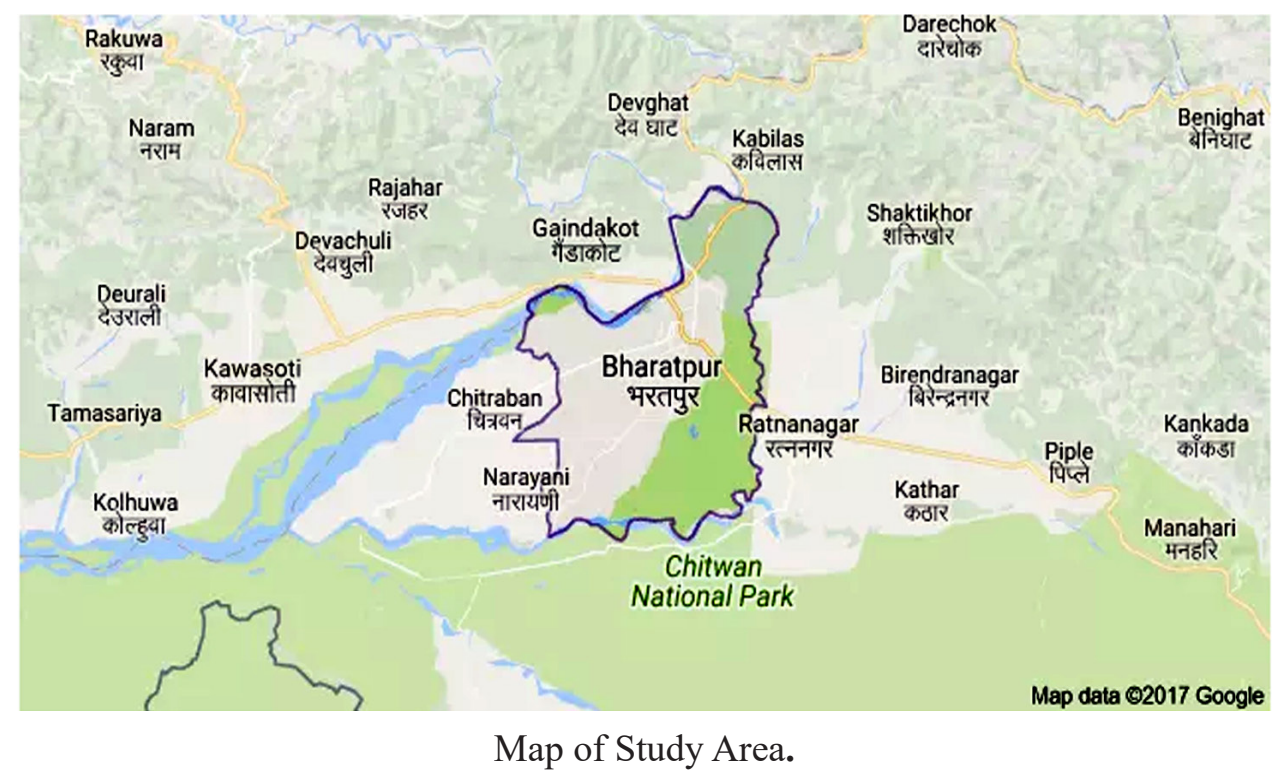

\subsection{Identification of Mammals:}

The identification of the mammals were performed with the help of books, 'Walker's Mammals of the World' $4^{\text {th }}$ edition (Nowak and Paradiso, 1983); 'Wild Mammals of Nepal' (Baral and shah, 2008); 'Mammals of Nepal' (Shrestha, 1997); and 'Indian Mammals' (Menon, 2014). The calls of mammals, body lengths, color patterns, tail length, fur size and marks left were also used in identification. The literature review through journals (IUCN, 2011 and 2018) and free Wikipedia were also used to compare the findings. The photographs were taken to ease identification.

\subsection{Data Analysis:}

The analysis of collected data was performed by tabulation (Table 1) and analysis with MSExcel so that the interpretation of the data was easily handled despite insufficient time and limited fund. The recorded mammals were categorized according to IUCN categories 2018. The IUCN categories were Critically Endangered (CR); Endangered (EN); Vulnerable (VU); Data Deficient (DD); and Least Concerned (LC).

\section{Result:}

The present study accomplished within 6 months from January to July 2016 in ex-situ area at Bharatpur Metropolitan City; revealed 12 families with 28 species of mammals (Table 1); which is $32.43 \%(12 / 37)$ of the total families and $14.58 \%(28 / 192)$ of total species in Nepal (Thapa, 2014). Out of 12 families; Soricidae had the highest, $21.43 \%(6 / 28)$ of species; followed by 
Cercopithecidae, Cervidae and Vespertilionidae, 10.71\% (3/28); Canidae, Felidae, Herpestidae, Muridae, and Viverridae, 7.14\% (2/28); and Mustelidae, Rhinocerotidae, and Suidae with $3.57 \%$ (1/28) each (Table 4). Total five different IUCN categories; CR, DD, EN, LC, and VU were reported. Out of them, LC had the highest, $64.29 \%(18 / 28)$; of species followed by VU, 21.43\% (6/28); EN, 7.14\% (2/28); and CR, DD equally with 3.57\% (1/28); (Table 2). Among 28 species, 53.57\% (15/28) were Temporary Living (TL) and 46.43\% (13/28); were Permanent Living (PL) mammals in the urban area (Table 3).

\begin{tabular}{|c|c|c|c|c|c|c|c|}
\hline \multirow{2}{*}{$\begin{array}{l}\text { S. } \\
\text { N. }\end{array}$} & \multicolumn{5}{|c|}{ Table 1: Checklist of Mammals. } & \multirow{2}{*}{$\begin{array}{l}\text { IUCN, } \\
2018\end{array}$} & \multirow{2}{*}{ Living } \\
\hline & Family & Genus & Species & $\begin{array}{c}\begin{array}{c}\text { Common } \\
\text { name }\end{array} \\
\end{array}$ & Local name & & \\
\hline 1 & Canidae & Canis & aureus & Golden Jackal & Shyal & $\mathrm{LC}$ & PL \\
\hline 2 & Canidae & Vulpus & bengalensis & Bengal Fox & Phyauro & VU & PL \\
\hline 3 & Cercopithecidae & Macaca & mulatta & $\begin{array}{l}\text { Rhesus } \\
\text { Macaque }\end{array}$ & Rato Bandar & $\mathrm{LC}$ & $\mathrm{TL}$ \\
\hline 4 & Cercopithecidae & Macaca & assamensis & $\begin{array}{l}\text { Assam } \\
\text { Macaque }\end{array}$ & $\begin{array}{l}\text { Asami Rato } \\
\text { Bandar }\end{array}$ & VU & $\mathrm{TL}$ \\
\hline 5 & Cercopithecidae & Semnopithecus & nipalensis & Grey Langur & \begin{tabular}{|l} 
Phetawal \\
Langur
\end{tabular} & $\mathrm{LC}$ & $\mathrm{TL}$ \\
\hline 6 & Cervidae & Axis & axis & Spotted Deer & Chital & VU & $\mathrm{TL}$ \\
\hline 7 & Cervidae & Axis & porcupinus & Hog Deer & Laguna & EN & $\mathrm{TL}$ \\
\hline 8 & Cervidae & Muntiacus & vaginalis & Barking Deer & Ratuwa & VU & $\mathrm{TL}$ \\
\hline 9 & Felidae & Felis & bengalensis & Leopard Cat & $\begin{array}{l}\text { Pate Ban } \\
\text { Biralo }\end{array}$ & VU & $\mathrm{TL}$ \\
\hline 10 & Felidae & Felis & chaus & $\begin{array}{l}\text { Common } \\
\text { Jungle Cat }\end{array}$ & Ban Biralo & $\mathrm{LC}$ & PL \\
\hline 11 & Muridae & Rattus & rattus & House Rat & Ghar Muso & $\mathrm{LC}$ & PL \\
\hline 12 & Muridae & Bandicota & bengalensis & Rat & $\begin{array}{l}\text { Sano Dhade } \\
\text { Muso }\end{array}$ & $\mathrm{LC}$ & PL \\
\hline 13 & Mustelidae & Martes & flavigula & $\begin{array}{l}\text { Yellow-throated } \\
\text { Marten }\end{array}$ & Mal-sapro & $\mathrm{LC}$ & $\mathrm{TL}$ \\
\hline 14 & Rhinocerotidae & Rhinoceros & unicornis & Rhinocerous & $\begin{array}{l}\text { Yak-singe } \\
\text { Gaida }\end{array}$ & $\mathrm{EN}$ & $\mathrm{TL}$ \\
\hline 15 & Sciuridae & Funambulus & pennanti & $\begin{array}{l}\text { Asiatic Striped } \\
\text { Palm Squirrel }\end{array}$ & Lokharke & $\mathrm{LC}$ & $\mathrm{TL}$ \\
\hline 16 & Soricidae & Episoriculus & caudatus & Asiatic Shrew & Chhuchundro & $\mathrm{LC}$ & PL \\
\hline 17 & Soricidae & Crocidura & attenuata & $\begin{array}{l}\text { Indo-chinese } \\
\text { Shrew }\end{array}$ & $\begin{array}{l}\text { Khairo } \\
\text { Chhuchundro }\end{array}$ & $\mathrm{LC}$ & PL \\
\hline 18 & Soricidae & Suncus & murinus & House Shrew & $\begin{array}{l}\text { Ghar } \\
\text { Chhuchundro }\end{array}$ & $\mathrm{LC}$ & PL \\
\hline 19 & Soricidae & Suncus & stoliczkanus & $\begin{array}{l}\text { Anderson's } \\
\text { Shrew }\end{array}$ & $\begin{array}{l}\text { Andersonko } \\
\text { Chhuchundro }\end{array}$ & $\mathrm{LC}$ & PL \\
\hline
\end{tabular}




\begin{tabular}{|l|l|l|l|l|l|c|c|}
\hline 20 & Soricidae & Crocidura & horsefieldii & $\begin{array}{l}\text { Horsefield's } \\
\text { Shrew }\end{array}$ & $\begin{array}{l}\text { Dhwanse } \\
\text { Chhuchundro }\end{array}$ & DD & PL \\
\hline 21 & Suidae & Sus & scrofa & $\begin{array}{l}\text { European } \\
\text { Wild Hog }\end{array}$ & Bandel & LC & TL \\
\hline 22 & Vespertilionidae & Myotis & formosus & Hodson's Bat & Chamero & LC & TL \\
\hline 24 & Vespertilionidae & Myotis & csorbai & $\begin{array}{l}\text { Csorb's Mouse- } \\
\text { eared Bat }\end{array}$ & Chamero & CR & TL \\
\hline 25 & Viverridae & Paradoxurus & hermaphroditus & $\begin{array}{l}\text { Toddy cat } \\
\text { Mouse-eared }\end{array}$ & Chamero & VU & PL \\
\hline 26 & Viverridae & Paradoxurus & h. pallasi & $\begin{array}{l}\text { Asian Palm } \\
\text { Civet }\end{array}$ & Malsapro & LC & TL \\
\hline 27 & Herpestidae & Herpestes & edwardsi & $\begin{array}{l}\text { Indian Grey } \\
\text { Mongoose }\end{array}$ & $\begin{array}{l}\text { Khairo Nyauri } \\
\text { Musa }\end{array}$ & LC & PL \\
\hline 28 & Herpestidae & Herpestes & javanicus & $\begin{array}{l}\text { Small Asian } \\
\text { Mongoose }\end{array}$ & $\begin{array}{l}\text { Sano Nyauri } \\
\text { Musa }\end{array}$ & LC & PL \\
\hline
\end{tabular}

\begin{tabular}{|c|c|c|c|c|}
\hline \multicolumn{5}{|c|}{ Table 2: IUCN Categories, 2018. } \\
\hline S.N. & IUCN, 2018 & Species No. & Total Species & Percentage \\
\hline 1 & CR & 1 & 28 & 3.57 \\
\hline 2 & DD & 1 & 28 & 3.57 \\
\hline 3 & EN & 2 & 28 & 7.14 \\
\hline 4 & LC & 18 & 28 & 64.29 \\
\hline 5 & VU & 6 & 28 & 21.43 \\
\hline & Total & $\mathbf{2 8}$ & $\mathbf{2 8}$ & $\mathbf{1 0 0 . 0 0}$ \\
\hline
\end{tabular}

Table 3: Living Nature of Mammals.

\begin{tabular}{|c|c|c|c|}
\hline S.N. & Living & Frequency & Percentage \\
\hline 1 & Permanent Living (PL) & 13 & 46.43 \\
\hline 2 & Temporaty Living (TL) & 15 & 53.57 \\
\hline & Total & $\mathbf{2 8}$ & $\mathbf{1 0 0 . 0 0}$ \\
\hline
\end{tabular}

\begin{tabular}{|c|l|c|c|c|}
\hline \multicolumn{5}{|c|}{ Table 4: Family-wise Percentage of Species. } \\
\hline S.N. & Family & Species No. & Total Species & Percentage \\
\hline 1 & Soricidae & 6 & 28 & 21.43 \\
\hline 2 & Cercopithecidae & 3 & 28 & 10.71 \\
\hline 3 & Cervidae & 3 & 28 & 10.71 \\
\hline 4 & Vespertilionidae & 3 & 28 & 10.71 \\
\hline 5 & Canidae & 2 & 28 & 7.14 \\
\hline 6 & Felidae & 2 & 28 & 7.14 \\
\hline 7 & Herpestidae & 2 & 28 & 7.14 \\
\hline
\end{tabular}




\begin{tabular}{|c|l|c|c|c|}
\hline 8 & Muridae & 2 & 28 & 7.14 \\
\hline 9 & Viverridae & 2 & 28 & 7.14 \\
\hline 10 & Mustelidae & 1 & 28 & 3.57 \\
\hline 11 & Rhinocerotidae & 1 & 28 & 3.57 \\
\hline 12 & Suidae & 1 & 28 & 3.57 \\
\hline Total & $\mathbf{1 2}$ & $\mathbf{2 8}$ & $\mathbf{2 8}$ & $\mathbf{1 0 0 . 0 0}$ \\
\hline
\end{tabular}

\section{Discussion and Conclusion:}

The study completed in Bharatpur Metropolitan City in an urban habitat for mammals; revealed 12 families of mammals with 28 species. The families represent $32.43 \%(12 / 37)$ and the species represents $14.58 \%$ (28/192) of total families and species reported from Nepal (Thapa, 2014). However, the species represents only $13.46 \%$ (28/208) of the total mammal species (Baral and Shah 2008). Among the families of mammals, the Family-Soricidae, had the highest, $21.43 \%$ $(6 / 28)$ of the species because the shrew were well adaptation in houses and garbage. The bats of the Family-Vespertilionidae (listed $10.71 \%$ ), were also adapted in the study area as it was close to the forest that helped them to hide in need. However, the deer of the Family-Cervidae (listed $10.71 \%$ ), were lured to the urban area during night especially for feeding on crop that increased the records of TL (listed 53.57\%). The mammals of the Family-Cercopithecidae (listed $10.71 \%$ ), like monkeys were fitted to live near the edge of the forest and the crop fields that facilitated hide and feeding opportunity. Sometimes unusual conflicts between wildlife and human arises and poisoning, electric shock may prevail in contradict to wildlife attacks to local people. Mammals of families like Canidae, Felidae, Herpestidae and Muridae included jackals and fox; wild cats; mongoose; rat and mice; respectively listed $10.71 \%$ of species of each. They had developed hide and sick behavior towards human and feel no threat to adapt closely with urban people. However, they are often killed in road accidents. The large mammals like rhinoceros of the Family-Rhinocerotidae, (listed 3.57\%) visit temporarily to urban areas for getting nutritious crops and other vegetables.

Felines, canines, and other carnivores are attracted by organic garbage, with unexpected feeding on neonatal human baby (Chaudhary, 2015); and anthropogenic shelters to live (Saito and Koike, 2013). The population status of viverrids, especially Paradoxurus hermaphrotus (Chaudhary, 2015); and P. h. pallasi is still unclear. Moreover, $P . h$. pallasii is reported for the first time from Bharatpur, Chitwan District, Nepal. The existence of pallasii was formerly reported from hilly area of Nepal (Pallas, 1777 and Gray, 1832), but the report did not clear about locations and their population.

The categories of mammals (IUCN, 2018), were reported where the Least Count (LC) had the highest, $64.29 \%$ in mammal species. The other categories were, Critically Endangered (CR), 3.57\%; Endangered (EN), 7.14\%; Vulnerable (VU), 21.43\%; and Data deficient (DD), 3.57\%.

The presence of mammals of delicate categories in urban area (IUCN, 2018); are in great threat due to cutting down of fruiting trees in private lands (Dickman, 1987). Therefore, study of 
urban wildlife helps to public mainly by two ways. One is: to reduce impact over endangered wildlife of native ecosystem; and other is: to develop more informed society about ecological importance of the urban wildlife.

\section{Recommendations:}

Following recommendations have been entertained so that it would be easier for the future planning of the nation and relevant agencies:

- Urban people should encourage plantation of flowering and fruiting trees in bare lands which increases wildlife to survive.

- Use of pesticides should be reduced or replaced by organic manures that increases preys.

- Awareness to people is essential which teach to use natural resources sustainably.

- Plantation of a tree in every house of the urban area is must.

- Regular records of IUCN or ZSL category of mammals should be kept.

- Repay of damaged crops should be encouraged to reduce wildlife conflicts.

- Legal protection should be promoted to check trade in animal products.

- The concerned authority should declare Bharatpur Metropolitan City as Important Wildlife Area (IWA).

\section{Acknowledgement:}

I would like to express my great pleasure and sincere thanks to Research Management Cell (RMC), Birendra Multiple Campus (TU), Bharatpur, Chitwan, Nepal to support with fund to accomplish my mini-research work.

\section{References:}

Baral, H.S. and K.B. Shah. 2008. Wild Mammals of Nepal. Himalayan Nature Kathmandu.

BN. 2018. Bharatpur Nepal (BN). https://en.wikipedia.org/wiki/Bharatpur,_Nepal.

CBD. 1997. National Report on Implementation of the Convention on Biological Diversity (CBD)

Nepal; 1997. His Majesty's Government of Nepal Ministry of Forest and Soil Conservation, Singhadurbar, Kathmandu. https://www.cbd.int/doc/world/np/np-nr-05-en.pdf. Accessed on 15 June, 2018.

CBD. 2014. Nepal Fifth National Report to Convention on Biological Diversity. Government of Nepal. Ministry of Forests and Soil Conservation, Singha Darbar, Kathmandu, Nepal. March 2014. https:// www.cbd.int/doc/world/np/np-nr-05-en.pdf. Accessed on 9 June, 2018.

CD. 2018. Chitwan District. https://en.wikipedia.org/wiki/Bharatpur,_Nepal. Accessed on 9 June, 2018. Chaudhary, Budhan. 2015. Surveillance on Nir Biralo (Toddy Cat) in Chitwan District. Vivek. Published by Birendra Multiple Campus, Chitwan. Year 31, Vol.10: 309-310.

CNP. 2018. 20https://en.wikipedia.org/wiki/Chitwan_National_Park (CNP).

Dickman, C.R. 1987. Habitat Fragmentation and Vertebrate Species Richness in an Urban Environment. J Appl Ecol 24: 337-351. Accessed on 11 June, 2018.

DNPWC. 2018. Department of National Parks and Wildlife Conservation. http://www.dnpwc.gov.np. Accessed on 11 June, 2018.

Gray, J.E. 1832. Asian Palm Civet. https://en.wikipedia.org/wiki/Asian_palm_civet. 
IUCN. 2011. The Status of Nepal's Mammals: The National Red List Series. https://www.ntnc.org. $\mathrm{np} /$ sites/default/files/publicaations/The\%20Status\%20of\%20Nepal\%27s\%20Mammals\%20-\%20 Red\%20List.pdf.

IUCN. 2018. The IUCN Red List of Threatened Species 2018. https://www.researchgate.net/ publication/330798390 The IUCN Red List of Threatened Species 2018 ${ }^{\mathrm{TM}}$ Technical Report • November 2018. DOI: 10.2305/IUCN.UK.2018-2. RLTS.T104651572A104651577.en. Citations 0 Reads.

Menon, V. 2014. Indian Mammals: A Field Guide. Hachette Book Publishing India Pvt. Ltd. ISBN 97893-5009-760-1. www.hachetteindia.com.

NEMC. 2017. Nepal Endemic Mammals Checklist. http://ntreasures.com/nepalb.html. Accessed on 9 June, 2018.

Nowak, R.M. and J.L. Paradiso. 1983. Walker's Mammal's of the World (4th edition). The Johns Hopkins University Press, Baltimore and London. Vol. 1 and 2.

Pallas, P.S. 1777. https://books.google.com.np/s?id=JgAMbNSt8ikC\&pg=PA551\&dq=paradoxurus+he rmaproditus + pallasii\&hl $=$ en\&sa $=X \& v e d=0$ ahUKEwi4s8OWzuzeAhXLKo8KHQwWAS4Q6AEINT $\mathrm{AC} \# \mathrm{v}=$ onepage $\& \mathrm{q}=$ paradoxurus $\% 20$ hermaproditus $\% 20$ pallasii\& $\mathrm{f}=$ false

Saito, M. and F. Koike. 2013. Distribution of Wild Mammal Assemblages along an Urban Rural Forest Landscape Gradient in Warm Temperate East Asia. PLoS ONE 8(5): e65464. doi:10.1371/journal. pone.0065464. Accessed on 11 June, 2018.

Shrestha, T.K. 1997. Mammals of Nepal. With Reference to those of India, Bangaladesh, Bhutan and Pakistan. R.K. Printers, Teku, Kathmandu, Nepal.

Thapa, S. 2014. A checklist of mammals of Nepal. https://www.researchgate.net/publication/270719769. doi:10.11609/JoTT.o3511.6061-72. Accessed on 11 June. 2018.

Wikipedia. 2017. List of Cities in Nepal. https://en.wikipedia.org/wiki/List_of_cities_in_Nepal. Accessed on 23 Nov. 2018.

WWF. 2012. The Status of Nepal's Mammals: The National Red List Series. http://www.wwfnepal. org/?206342/The-Status-of-Nepals-Mammals. Accessed on 23 Nov. 2018. 